\title{
Lupoid cutaneous leishmaniasis in Afghanistan treated with $0.045 \%$ DAC N-055
}

\author{
KW Stahl ${ }^{\text {** }}$ IG Sakhayeee ${ }^{2}$ \\ From International Conference on Prevention \& Infection Control (ICPIC 2011) \\ Geneva, Switzerland. 29 June - 2 July 2011
}

\section{Introduction / objectives}

Lupoid leishmaniasis (LCL) is a rare, face disfiguring, treatment resistant complication which has responded to the expensive photodynamic therapy in 5 patients in Iran [ F. Ghaffarifar et al. La Rev. de la Méditerranée orientale Vol. 12 No. 6, 2006]. Here we report 5 cases,photodocumented as best as we could under the actually disastrous conditions of Afghan Health Care,- treated with 0.045\% DAC N-055 [German Drug Codex, 1990], which is split into ${ }^{1} \mathrm{O}_{2}$ and $2 \mathrm{NaClO}_{2}$ after $360 \mathrm{~nm}$ light exposure and reacts as chlorite in iodometry.

\section{Methods}

The faces of 5 patients with a CL anamnesis and clinically diagnosed as lupoïd CL were treated daily for the first week with $0.045 \%$ DAC N-055 prepared in basic crème DAC B-20 under occlusive dressings, thereafter the patients were instructed to treat themselves with this hydrophilic crème and were told to show up as outdoor patients at least once per fortnight. Pharmaceutical chlorite, $\mathrm{NaClO}_{2}$ [monograph DAC N-055] is $\mathrm{O}_{2}$ enriched due to its $\mathrm{Na}_{2} \mathrm{Cl}_{2} \mathrm{O}_{6}$ content, formerly called TCDO, $\left(\mathrm{NaClO}_{2}\right)_{4} \cdot \mathrm{O}_{2}$, which fights viral, bacterial or parasitic tissue infections and promotes wound granulation even in radiogenic ulcers [http://www-pub.iaea.org/ $\mathrm{mtcd} /$ publications/pdf/te_1300_web.pdf].

\section{Results}

1 patient was lost, 4 patients healed completely without scarring and with excellent cosmetic results (see photos!), 3 within 3 months, 1 after 10 months because of an additional severe eczema. There were no clinical signs of recurrence, one patient was followed for 6 years.

W'Waisenmedizin e. V., Freiburg i. Brsg., Germany

Full list of author information is available at the end of the article

\section{Conclusion}

The low treatment costs for such excellent cosmetic results are appropriate for poor Afghan patients.

\section{Disclosure of interest}

None declared.

\section{Author details}

${ }^{1}$ Waisenmedizin e. V., Freiburg i. Brsg., Germany. ${ }^{2}$ Dermatology, Balkh Civil Hospital, Mazar-e-Sharif, Afghanistan.

Published: 29 June 2011

doi:10.1186/1753-6561-5-S6-P247

Cite this article as: Stahl and Sakhayeee: Lupoid cutaneous leishmaniasis in Afghanistan treated with 0.045\% DAC N-055. BMC Proceedings 20115 (Suppl 6):P247.
Submit your next manuscript to BioMed Central and take full advantage of:

- Convenient online submission

- Thorough peer review

- No space constraints or color figure charges

- Immediate publication on acceptance

- Inclusion in PubMed, CAS, Scopus and Google Scholar

- Research which is freely available for redistribution
() Biomed Central

\section{() Biomed Central}

